\title{
Nina Bonderup Dohn \& Lars Johnsen: E-laering på web 2.0. Frederiksberg: Samfundslitteratur. 2009.
}

\section{Jørgen Bang}

MedieKultur 2010, 49, 190-193

Published by SMID | Society of Media researchers In Denmark | www.smid.dk The online version of this text can be found open access at www.mediekultur.dk

E-læring på web 2.0 definerer sig selv som "en lærebog om web 2.0 i teori og i praksis, anskuet ud fra såvel en teknologisk som en kommunikations- og læringsteoretisk vinkel” (p. 9). Et langt stykke hen ad vejen holder denne varedeklaration. Bogen indeholder mange gode ideer og relevante præsentationer af web 2.0 som e-læringsværktøj i et tilegnelsesperspektiv samtidig med, at den i andre afsnit promoverer en forståelse af læring som ren deltagelse. Denne modstilling understreges af bogens opbygning, hvor de første kapitler giver en meget pragmatisk introduktion til e-læring og web 2.0, mens kapitlerne 8 og 9 (del 3) anlægger en teoretisk og i kapitel 8 også ideologisk forståelse. I anmeldelsen forsøger jeg at bringe sammen, hvad bogen forsøger at adskille, med henblik på at få en samlet forståelse af forfatternes tilgang til e-læring og web 2.0.

Kapitel 1 giver en bred beskrivelse af de forskellige typer af software, der har fået betegnelsen "web 2.0" og optræder på web 2.0-websites som YouTube, Flickr, Wikipedia, Facebook, Delicious og på blogs af forskellig slags. Samtidig karakteriseres de typiske træk ved web 2.0-sites i forhold til de gamle web 1.0-sites.

I samme kapitel argumenteres der også for, hvorfor bogen anlægger to synsvinkler på fænomenet web 2.0. En teknologisk, der påpeger de potentialer for informationsstrukturering og standardisering, som brug af det åbne dataformat XML giver i forhold til HTML. Og en kommunikations- og læringsteoretisk, der fremhæver mulighederne for "brugerdeltagelse, peer-evaluering og kollaborativ meningsproduktion" (p. 19).

Den teknologiske synsvinkel foldes ud i kapitel 2 i en glimrende oversigt over de tek- 
niske komponenter i de forskellige web 2.0-teknologier: wiki og blogs, tagging-systemer, formaterne HTML og XML, RRS og mash-ups. Dette spor føres i bogen videre i det afsluttende kapitel 9, hvor organisering af læringsindhold og -materialer med XML diskuteres med udgangspunkt i CNXML, der anvendes til opmærkning af modulært læringsindhold. Desværre er præsentationen af denne problemstilling meget teknisk orienteret og forudsætter et dybere kendskab til det omtalte opmærkningssprog. Retfærdigvis skal det siges, at læseren advares om dette allerede i bogens forord.

Foruden det teknologiske spor og det kommunikations- og læringsteoretiske spor, som jeg kommer til nedenfor, rummer bogen to kapitler, som gør rede for henholdsvis "Åbne e-læringsressourcer og -objekter på web 2.0" (kapitel 6) og "Kvalitet og kvalitetssikring på web 2.0" (kapitel 7). Begge er gode introduktioner til emnerne med henvisninger til relevante eksempler.

Kapitel 6 definerer således begrebet "Open Educational Resources" og præsenterer idégrundlaget for det alternative copyright system "Creative Commons". Som eksempler på portaler, der har samlet adgangen til åbne læringsressourcer, præsenteres "Open Educational Ressource Index" og "OER Commons", mens "MITOpenCourseWare" og "OpenLearn" fra Open University, UK (OUUK), trækkes frem som eksempler på universiteter, der lægger deres læringsressourcer åbent frem til fri anvendelse. MIT startede dette initiativ i 2002, mens OUUK først er kommet på banen i de seneste år. Til gengæld er deres inkorporering af web 2.0-faciliteter mere avanceret. Også "Wikibooks", der understøtter kollaborativ skrivning af lærebøger, og "Connexions", der er udviklet til at skabe modulære e-læringsobjekter i XML på Rice University, diskuteres med henblik på deres anvendelighed som kollaborative værktøjer.

Sidst i kapitel 6 diskuteres, hvorfor der i undervisningsverdenen er en relativt stor skepsis blandt underviserne over for web-baserede ressourcer. Kultur, tradition, manglende teknologiske kompetencer og mediets fysiske form angives som årsager sammen med kvalitetssikringen, som er emnet for kapitel 7. Med udgangspunkt i en sammenligning mellem Encyclopaedia Britannica og Wikipedia, som tidsskriftet Nature gennemførte i 2005, og som viste, at fejlmængden i Wikipedia ikke afveg graverende fra Encyclopaedia Britannica, diskuteres fordelene ved elektroniske leksika. Også mulige former for fagfællebedømmelse - peer-reviews - tilpasset den elektroniske form trækkes frem med fremhævelse af de "godkendelsesfiltre", som det er muligt at integrere i "Connexions".

Bogens kommunikations- og læringsteoretiske spor må ud fra dens titel betragtes som det væsentligste. Sidste del af første kapitel redegør for, hvordan web 2.0 kan anvendes til e-læring og bl.a. understøtte og kvalificere underviserens arbejde, bidrage til organiseringen af fleksibel læring, fremme motivationen hos den lærende, tilbyde nye didaktiske muligheder og udvikle den lærendes generelle kompetence inden for e-literacy. Mere specifikt udfoldes potentialerne i brugen af web $2.0 \mathrm{i}$ kapitel $3 \mathrm{om}$ "Blogs som læringsredskab", kapitel 4 om "Wikier som læringsredskab" og kapitel 5 om "Social software som læringsredskab 
- 'læring på tværs"' for at blive sat ind i en læringsteoretisk ramme i kapitel 8 om "Læringsbegreber i spil med web 2.0-medieret e-læring".

Kapitlerne 4, 5 og 6 er parallelt opbygget med et indledende fokus på de didaktiske mål, der bør afklares, når web 2.0-værktøjer anvendes i undervisningen, efterfulgt af eksempler på forskellig anvendelse af de respektive værktøjer. Især kapitel 4 og 5 giver mange gode eksempler på, hvordan henholdsvis blogs og wikier er blevet anvendt i undervisningen, og opnår samtidig at få fremhævet deres forskellige kommunikative styrker og svagheder. Et gennemgående eksempel i begge kapitler er et kursus, som den ene forfatter gennemførte på Syddansk Universitet i faget Webkommunikation. Derudover fremlægges eksempler fra andre undervisningsinstitutioner og eksempler hentet fra international forskning. Sidst i hvert af de to kapitler diskuteres, hvordan pointerne i eksemplerne, som overvejende er fra videregående uddannelser, kan have relevans for grundskolen og ungdomsuddannelserne. I kapitel 5 er fokus i eksemplerne ikke på forskellig anvendelse af samme værktøj, men på forskellige typer af social software: Second Life, Facebook og mobiltelefoner.

Fælles for de tre kapitler er nogle gennemgående overvejelser over lærerrollen i de forelagte eksempler. Hvor meget skal underviseren tilrettelægge og stille af krav? Hvor meget skal han/ hun kommentere indlæg og rette i dem? Diskussionerne virker uforløste og skaber undren hos læseren, men i kapitel 8 kommer så forklaringen: De er et led $\mathrm{i}$ en argumentation for et læringssyn, som kun svagt er blevet præsenteret i første kapitel. Forfatterne skelner skarpt mellem "læring som tilegnelse" og "læring som deltagelse" (med inspiration fra Sfard, 1998) og placerer på meget forenklet vis alle læringsteoretiske tilgange, som argumenterer for, at viden er noget, der kan tilegnes/kommunikeres og understøttes af institutionelle rammer, i samme bås (behaviorisme, kognitivisme, konstruktivisme og virksomhedsteori). Deltagerperspektivet potenseres med henvisning til "situated learning" og "communities of practice" i en sådan grad, at begrebet om "reframing" (Lave \& Wenger, 1991) af tidligere forståelser og dermed refleksion er fraværende. Web 2.0 bliver synonymt med deltagelse og indbegrebet af læring.

I en paradisisk verden uden magtrelationer og befolket med videbegærlige individer $\mathrm{i}$ et samfund med rigelige materielle ressourcer er læring gennem deltagelse en smuk tanke, og der er ingen tvivl om, at læringsaktiviteter og interaktion med læringsressourcer og medstuderende/"peers" er væsentlige for læring, men i kapitel 8 nærmer vi os aflæggelse af en trosbekendelse. Den nøgternhed og præcision, som præger bogens andre afsnit om web 2.0, bliver her ideologisk. Et af problemerne er, at web $2.0 \mathrm{i}$ den læringsteoretiske redegørelse betragtes som ét fænomen og ikke som en række værktøjer med forskelligt sigte, hvor blogs og wikier tilhører én gruppe, der organiserer viden med mulighed for interaktion/kommentering/udbygning, mens Facebook og lignende værktøjer tilhører en anden, som i overvejelse grad understøtter, hvad Roman Jakobson benævner fatisk kommunikation.

Alt $\mathrm{i}$ alt er min vurdering af E-laring på web 2.0 altså ambivalent. Bogen indeholder mange gode ideer og relevante præsentationer af web 2.0 som e-læringsværktøj i et tileg- 
Book Review: E-læring på web 2.0

nelsesperspektiv samtidig med, at den i andre afsnit promoverer en forståelse af læring som ren deltagelse.

Jørgen Bang

Lektor

Center for IT og laering

Aarhus Universitet

jbang@imv.au.dk 